\title{
Article \\ A Preliminary Study on Effects of Fermented Feed Supplementation on Growth Performance, Carcass Characteristics, and Meat Quality of Hanwoo Steers during the Early and Late Fattening Period
}

\author{
Dahye Kim ${ }^{1,+}$, Jeong-Sung Jung ${ }^{2,+}$ and Ki-Choon Choi ${ }^{2, *}$ \\ 1 Faculty of Biotechnology, College of Applied Life Science, Jeju National University, Jeju 63243, Korea; \\ dahyekim@jejunu.ac.kr \\ 2 Grassland and Forages Division, National Institute of Animal Science, Rural Development Administration, \\ Cheonan 31000, Korea; jjs3873@korea.kr \\ * Correspondence: choiwh@korea.kr; Tel.: +82-41-580-6752; Fax: +82-41-580-6779 \\ $\dagger$ These authors contributed equally to this work.
}

\section{check for}

updates

Citation: Kim, D.; Jung, J.-S.; Choi, K.-C. A Preliminary Study on Effects of Fermented Feed

Supplementation on Growth

Performance, Carcass Characteristics, and Meat Quality of Hanwoo Steers during the Early and Late Fattening Period. Appl. Sci. 2021, 11, 5202. https://doi.org/10.3390/app11115202

Academic Editor:

Alessandra Durazzo

Received: 29 March 2021

Accepted: 1 June 2021

Published: 3 June 2021

Publisher's Note: MDPI stays neutral with regard to jurisdictional claims in published maps and institutional affiliations.

Copyright: (c) 2021 by the authors. Licensee MDPI, Basel, Switzerland. This article is an open access article distributed under the terms and conditions of the Creative Commons Attribution (CC BY) license (https:// creativecommons.org/licenses/by/ $4.0 /)$.
Abstract: The present study was conducted to determine the effects of formulated feed (IRG: Italian ryegrass, WCC: whole crop corn, and fermented feed) on growth performance, carcass characteristics, and meat quality of Hanwoo steers during early and late fattening periods. Twelve Hanwoo steers were randomly assigned into two groups: control and treatment ( $n=6 /$ group). The control group received rice straw with concentrate; the Treatment group received formulated feed for 13 months. Results revealed that formulated feed supplementation significantly $(p<0.05)$ increased effects on dry matter (DM) intake, body weight, average daily gain, and carcass yield than control feed. Hanwoo steers fed formulated feed showed higher meat quality, carcass yield, and ribeye area than steers fed control feed. However, meat quality characteristics (such as cooking loss, fat thickness, marbling score, meat color, and crude fat), sensory characteristics, and $\mathrm{pH}$ values were similar between the two groups (all $p>0.05$ ). There was no significant difference in FA compositions of steers between the two groups $(p>0.05)$. Overall, these results indicate that feeding Hanwoo steers with formulated feed can improve their growth efficacy, carcass yield, and meat quality characteristics during early and late fattening periods. Regarding an economic strategy, our research findings suggest that formulated feed is effective and profitable for feeding Hanwoo steers during early and late fattening periods without causing adverse effects.

Keywords: formulated feed; WCC; IRG; concentrate; rice straw; growth; carcass; economic strategy

\section{Introduction}

In recent years, feed production costs have increased by $70-80 \%$ in the livestock industry largely due to dietary demands for raw materials. Particularly, Korea imports $60 \%$ of feed grains for livestock animals from other countries. This rising feed cost directly affects domestic livestock farms. It is well-recognized that feed plays a key role in modulating fatty acid compositions of livestock, goats, and sheep. Feed is considered the most important factor in livestock production. Its cost is often higher than half of the production cost. To overcome this issue, the Korean Government, the livestock industry, and farmers have paid more attention to the production of new low-cost alternative feedstuffs for livestock [1] The Korean native beef cattle Hanwoo are a crossbreed of Bos Taurus $\times$ Bos Taurus. It is the major producer of cattle meat, yielding extremely marbled beef. It accounted for roughly $85 \%$ of all slaughtered cattle in 2017 [2]. Hanwoo steers are typically fattened until nearly 30 months of age. They are fed high-density concentrate diets during the fattening period to obtain a high level of marbling. Lee et al. [3] have reported that the marbling of Hanwoo steers can be substantially enhanced between the ages of 12 and 27 months. Marbling is 
one of the key factors deciding Hanwoo quality grade. It can improve by feeding highdensity concentrate diets [4]. However, feeding high-density concentrate diets during the final fattening cycle might have negative impacts on digestive metabolism, feed quality, and feed intake [5]. In addition, the demand for highly marbled beef has increased. Thus, beef producers have recently increased their use of grain-based feeds during the fattening season. Concentrate feed contains an excessive amount of fermentable carbohydrate, causing acidosis in cattle. During the fattening period, replacing animal-based materials with plant-based materials or microbially fermented feed can prevent acidosis and preserve the integrity and health of ruminal papillae and nutrient absorption [6]. Nowadays, large amounts of concentrate are formulated with grass or whole-grain cereals, among other items, to provide energy, protein, and essential nutrients to animals. They have been used to fatten cattle in Korea despite the fact that such feed can cause excessive drops in ruminal $\mathrm{pH}$ during the late fattening period [7]. Grain crops, such as maize, are increasingly being moved to the energy market from agricultural markets for food and feed. As a result, there is competition for biomass as bioenergy raises forecasts of international grain prices [8]. Therefore, the use of other types of feeds, such as grass, to replace grain-based feeds must be investigated.

Grass and grass-based feeds are inexpensive and low-cost natural sources of highquality roughage for ruminants. Furthermore, grass-fed cattle have a wide range of polyunsaturated fatty acids (PUFAs), saturated fatty acids (SFAs), and conjugated linoleic acid. Animal nutrition has a significant effect on fatty acid (FA) compositions and animal proteins. Beef quality is primarily dependent on fat content and FA compositions $[9,10]$. Owing to the strong market demand in South Korea, Hanwoo steers have a fattening period before slaughter. In general, beef skeletal muscles have large amounts of polyunsaturated fatty acids, such as alpha-linolenic acid, linoleic acid, and oleic acid, all of which have health benefits for consumers. Meat production processes should attempt to comprise grass-enriched beef production systems while meeting consumer quality standards in terms of food quality at the same time [2] to satisfy retailer and customer demands. However, fat from grass-finished beef has been confirmed to have a yellowish appearance due to an increased level of carotenoid, suggesting that grass-rich feeds can adversely affect the quality of the meat [11]. A higher concentrate in forage-based feeds for fattening ruminants can improve the quality of meat production. When the concentrate is added to a forage feed, the efficiency of using absorbed nutrients to synthesis animal tissues or products is typically enhanced. Furthermore, mixing concentrate and forage in the feed can optimize ruminant fattening and result in faster and more productive growth as well as heavier carcasses than either concentrate or forage alone. When fresh forage is added to the feed of lactating buffalo, the percentage of unsaturated fatty acids is increased while the percentage of short-chain fatty acids is decreased. Additionally, sensory characteristics are altered by forage without influencing consumers. It has been concluded that replacing green fodder in the feed is a low-cost feeding strategy for improving buffalo health [12].

Forages, including Italian ryegrass (IRG), corn, alfalfa, and wheat straw, are important for the healthy production of the rumen in ruminants. The quality of roughage has a significant impact on productivity [13]. Total mixed ratio (TMR) is commonly used for dairy cattle production in Korea. It was first introduced to Hanwoo in the 2000s. TMR is a complete feed consisting of forage, concentrate, minerals, vitamins, protein feeds, and other additives in certain portions. It is of great interest to farmers because it has promising benefits for the management and development of ruminants [14]. Farmers raising domestic-bred fattening cattle have an interest in fibroid feed materials, such as TMR, over-concentrate, because these cattle need more feed intake for rapid gains of body weights [15]. It has been evidenced that feedstuff has a key function in feed consumption, preservation of homeostasis of ruminant $\mathrm{pH}$, minimizing the occurrence of metabolic disease, maximizing milk production enhance their lifetime, and decreasing labor input [16]. Xie et al. [17] stated that the performance of TMR feed and milk production is improved compared to individual feeds. Feeding TMR is appropriate with the addition of high 
humidity agriculture by-products. Silage, feed, and straw are typical roughages used in TMR.

Fermentation is a process that plays a significant role in the use of potential nutrients for improving their conservation and reducing anti-nutritional substances in a TMR/silage process. Lactic acid bacteria (LAB) have been widely used as inoculants in most silage processes due to their higher efficiency for containing lower levels of acetic acid and butyric acid. Furthermore, LAB can control unwanted microbial growth in ensiled silages. For example, L. plantarum is a lactic acid bacterium known to play an important role in the nutritional enhancement of silages through the production of lactic acid and other metabolites during the ensiling process as a preventive additive to silage and haylage production [18-20]. Fermented TMR (FTMR) is a concentrated mixture fermented under anaerobic conditions (i.e., ensiling). It may reduce anti-nutritive substances, such as mimosin or hydrocyanic acid (HCN). Kim et al. [21] studied FTMR after the addition of lactic acid bacteria and fermentation for 21 days and demonstrated that it could improve feed intake and growth efficiency in Hanwoo steers compared to the control. However, the benefits of feeding microbially fermented feed and control feed to Hanwoo steers from the early period to the late fattening period have not been reported yet. It is important to perform feeding trials to compare formulated feed combined with silage and a conventional rice straw combined with a concentrate-based system and determine the effects of the formulated feed/concentrate feeding system on Hanwoo steers. Thus, the main objective of this study was to compare growth efficiency, carcass quality, and meat quantity and quality characteristics of Hanwoo steers fed formulated feed with those fed control feed.

\section{Materials and Methods}

\subsection{Collection of Crops and Silage Production with Lactic Acid Bacteria}

Italian ryegrass (IRG) and corn were cultivated at the Daum Hanwoo farm, Jeongeup, Jeollabuk-do, South Korea. IRG at early flowering and whole crop corn (WCC) at the yellow ripening stage were harvested and wilted in the field condition for two days. After reaching expected moisture (60-65\%), the harvested samples were applied with lactic acid bacteria by automatic spraying method (Mixture of three Lactobacillus plantarum K46, KCC-10, and KCC-19, $100 \mathrm{~g} / 50$ tons, Top silage, Jeongeup, Korea) and packed in a round bale using the wrapping machine. LAB was prepared in sterile distilled water before silage preparation [22].

\subsection{Fermented Feed Preparation}

Fermented feed (FF) was prepared following user guidelines of Innobio Corporation (Innobio Co, Shiheung, Korea) according to feed composition standard tables provided by the National Institute of Animal Science, which included cornflake, corn gluten feed, distillers dried grains, rice bran (fermented by microbes), limestone, and vitamin premix, with three microbial strains (L. plantarum, B. subtilis, and S. cerevisiae) maintained at an optimal temperature of $25^{\circ} \mathrm{C}$ for 3 to 6 days under aerobic conditions to accomplish proper fermentation. Subsequently, FF was moved to a feed mixer (DW330-22, Dongwoo Solution Co., Changwon, Korea) through a conveyor system.

\subsection{Animal and Experimental Design}

This experimental study was designed and performed according to animal care and standard guidelines of the National Institute of Animal Science, South Korea (Approval Number NIAS-2020-443, Approval date: 17 February 2020). Twelve Hanwoo steers were obtained at 13 months old and were kept in individual cages located at the Daum Hanwoo farm, Jeongeup, Jeollabuk-do, South Korea. These animals were divided into two groups; the control and treatment group, each consist of 6 animals. The initial body weight for the control group was $376.4 \mathrm{~kg}$, and the treatment group was $415 \mathrm{~kg}$. Feeding system: Control group received rice straw with concentrate, Treatment group received formulated feed (IRG, WCC silages, and fermented feed (FF)) for 13 months, according to growth 
steps following the Korean feeding standard (Figure 1). In detail, from the early fattening period (6 months), the control group animals received rice straw $(3.5 \mathrm{~kg})$, with concentrate $(8 \mathrm{~kg})$, treatment group animals received fermented IRG $(3 \mathrm{~kg})$, WCC $(5.86 \mathrm{~kg})$, and feed $(7.43 \mathrm{~kg})$ without concentrate. From the late fattening period ( 7 months), control group animals received rice straw $(1.79 \mathrm{~kg})$, with concentrate $(12.57 \mathrm{~kg})$, treatment group animals received rice straw $(0.79 \mathrm{~kg})$, Fermented IRG $(1.29 \mathrm{~kg})$, WCC $(0.43 \mathrm{~kg})$, feed $(8.86 \mathrm{~kg})$ and concentrate $(6.43 \mathrm{~kg})$. Water was provided to animals ad libitum every day. They were fed the experimental feed twice daily at 9.00 and 16:00. They had ad libitum access to water. During the study period, their average body weight, daily gain, and feed intake were measured.

\begin{tabular}{c|c|c|}
\multirow{2}{*}{ Control Group (n=6) } & \multicolumn{2}{c}{ Early Fattening period (6months) } \\
& Concentrate + Rice Straw & Concentrate + Rice Straw \\
\hline
\end{tabular}

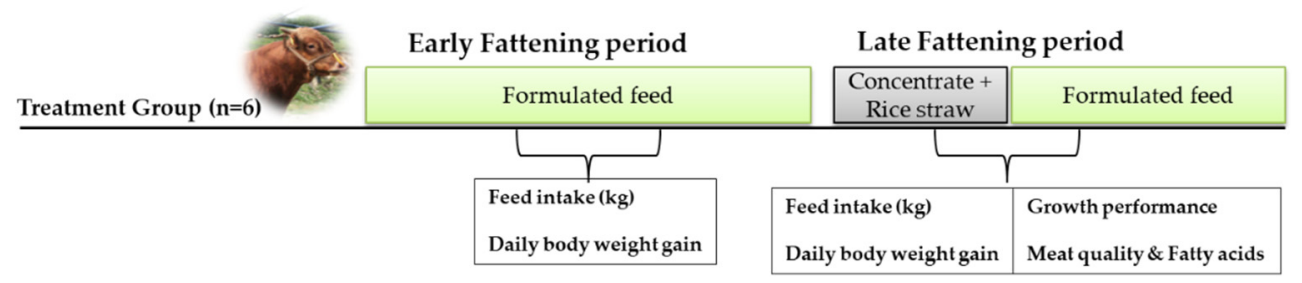

Figure 1. Experimental design and animal feeding system for concentrate and formulated feed.

\subsection{Nutrient Profiles of RICE Straw and Silages}

Random grab samples of rice straw, IRG silage, and WCC silage were ground through a $1 \mathrm{~mm}$ screen for proximal determination. Dry matter content (DM) of rice straw was examined after drying in an air-dryer at $65^{\circ} \mathrm{C}$ for 3 days using AOAC and DM of forage silage examined after drying in a freeze-dryer at $-80^{\circ} \mathrm{C}$ for $3-5$ days [23]. Crude protein $(\mathrm{CP})$, ether extract (crude fat), neutral detergent (NDF), and acid detergent (ADF) were determined $[24,25]$. Digestible energy values were calculated from total digestible nutrients (TDN) [26]. Chemical compositions of rice straw, Italian ryegrass silage, and corn silage are shown in Table 1. Ingredients and chemical compositions of concentrate and fermented feed are presented in Table 2.

Table 1. Nutrient compositions of rice straw, Italian ryegrass (IRG) silage, and WCC silage.

\begin{tabular}{cccc}
\hline Item (\% DM) & Rice Straw & IRG Silage & WCC Silage \\
\hline Dry matter (DM) & $88.50 \pm 0.40$ & $65.04 \pm 0.84$ & $68.04 \pm 0.34$ \\
Crude protein (CP) & $4.40 \pm 0.05$ & $8.40 \pm 0.13$ & $8.69 \pm 0.50$ \\
Acid detergent fiber (ADF) & $42.10 \pm 0.19$ & $39.41 \pm 0.43$ & $31.20 \pm 2.29$ \\
Neutral detergent fiber (NDF) & $69.09 \pm 0.12$ & $66.85 \pm 0.43$ & $46.82 \pm 2.12$ \\
Total digestible nutrient (TDN) & $55.65 \pm 0.15$ & $57.77 \pm 0.34$ & $68.06 \pm 0.97$ \\
\hline
\end{tabular}

\subsection{Carcass Characteristics and Meat Quality}

At the end of the experimental period, all steers were killed at a commercial abattoir regulated by the National Agricultural Cooperative Federation, Korea (KOR) to determine carcass characteristics and meat quality. Immediately after the slaughter process, carcasses were weighed and then chilled for $48 \mathrm{~h}$ at $4{ }^{\circ} \mathrm{C}$. Intramuscular samples were taken from the 13-14th ripples, ground, and mixed well to determine fatty acids of $M$. longissimusdorsi (LM). Grade of quantity $(5=$ grade $\mathrm{A}$ to $2=$ grade $\mathrm{D})$, marbling $(1=$ low-fat to $5=$ high fat $)$, color of meat $(1=$ very bright cherry red to $7=$ very dark red $)$, color of fat $(1=$ white to $7=$ yellow $)$, texture $(1=$ very smooth to 3 very coarse $)$, maturity $(1-15 \mathrm{~mm}$ to $15-26 \mathrm{~mm}$ old $=2)$, 
and grade of quality $(7=$ grade $1+$ to grade $3=1)$ were assessed. Backfat thickness was measured perpendicular to the outside surface at a point two-thirds the length of the ribeye between the last rib and the first lumbar vertebrae. The area of the ribeye at the surface of the cut was calculated using a standard grid. Ten grams of chopped meat was combined with ten milliliters of deionized water, and the $\mathrm{pH}$ of the slurry was determined using a pH meter (F-12, Horiba, Kyoto, Japan). Cooking loss was measured as described by Kang et al. [27]. A cooking loss sample was then used to calculate shear force. The sample was cut into $1.5 \mathrm{~cm}$ length and $1 \mathrm{~cm}^{2}$ cross-section with the fiber direction. A texture analyzer (TA-XT2i, Stable Microsystems Ltd., Surrey, UK) equipped with a $25 \mathrm{~kg}$ load cell and a Warner-Bratzler shear blade at a test speed of $2.0 \mathrm{~mm} / \mathrm{s}$ was used to determine the shear force. Only the maximum force $(\mathrm{kg})$ was considered. A portion of the meat sample was cut into $2 \mathrm{~cm}$ wide, $4 \mathrm{~cm}$ long, and $0.5 \mathrm{~cm}$ thick pieces and roasted in a home-use electronic pan until an internal temperature reached $73^{\circ} \mathrm{C}$.

Table 2. Ingredient compositions and chemical analysis of concentrate and fermented feed.

\begin{tabular}{|c|c|c|c|}
\hline Concentrate Feed & (DM \%) & Fermented Feed (FF) & (DM \%) \\
\hline Ingredients & & Ingredients & \\
\hline Corn grain & 27.47 & Cornflake & 73.50 \\
\hline Wheat grain & 17.00 & Corn gluten feed & 10.00 \\
\hline Cane molasses & 5.00 & Distillers dried grains & 5.00 \\
\hline Tapioca & 6.00 & Rice bran & 10.00 \\
\hline Wheat flour & 3.00 & Probiotics & 0.10 \\
\hline Corn gluten feed & 20.00 & - & - \\
\hline Rapeseed meal & 4.00 & - & - \\
\hline Palm kernel meal & 8.82 & - & - \\
\hline Cottonseed hull & 1.00 & - & - \\
\hline Tallow & 0.62 & - & - \\
\hline Salt dehydrated & 0.50 & - & - \\
\hline Limestone (1 mm) & 1.96 & Limestone (1 mm) & 1.40 \\
\hline Vitamin premix ${ }^{a}$ & 0.10 & Vitamin premix $^{c}$ & 0.10 \\
\hline Mineral premix ${ }^{b}$ & 0.10 & - & \\
\hline Chemical Compositions & & Chemical Compositions & \\
\hline Dry matter (DM) & 88.68 & Dry matter (DM) & 73.5 \\
\hline Crude protein $(\mathrm{CP})$ & 12.90 & Crude protein $(\mathrm{CP})$ & 11.25 \\
\hline Ether extract & 3.76 & Ether extract & 6.59 \\
\hline Crude fiber & 6.10 & Crude fiber & 3.68 \\
\hline Calcium & 0.91 & Calcium & 0.03 \\
\hline Phosphorous & 0.41 & Phosphorous & 0.36 \\
\hline Crude ash & 6.62 & Crude ash & 2.07 \\
\hline Acid detergent fiber (ADF) & 22.50 & Acid detergent fiber (ADF) & 2.93 \\
\hline Neutral detergent fiber (NDF) & 35.50 & Neutral detergent fiber (NDF) & 14.60 \\
\hline Total digestible nutrient (TDN) & 73.00 & Total digestible nutrient (TDN) & 86.69 \\
\hline
\end{tabular}

a Vitamin premix contained the following ingredients diluted in cellulose (g/kg premix): L-ascorbic acid, 121.2 DL- $\alpha$-tocopherol acetate, 18.8; thiamine hydrochloride, 2.7; riboflavin, 9.1; pyridoxine hydrochloride, 1.8; niacin 36.4; Ca-D-pantothenate, 12.7; myoinositol, 181.8; D-biotin, 0.27; folic acid, 0.68; p-aminobenzoic acid, 18.2; menadione, 1.8; retinal acetate, 0.73; cholecalciferol, 0.003; cyanocobalamin, 0.003 . ${ }^{\mathrm{b}}$ Mineral premix contained the following ingredients (g/ kg premix): $\mathrm{MgSO}_{4} \_7 \mathrm{H}_{2} \mathrm{O}, 80.0 ; \mathrm{NaH}_{2} \mathrm{PO}_{4} 2 \mathrm{H}_{2} \mathrm{O}, 370.0 ; \mathrm{KCl}, 130.0$; ferric citrate 40.0; $\mathrm{ZnSO}_{4}{ }_{7} \mathrm{H}_{2} \mathrm{O}, 20.0$; Ca-lactate, 356.5; $\mathrm{CuCl}, 0.2 ; \mathrm{AlCl}_{3} \_6 \mathrm{H}_{2} \mathrm{O}$. 0.15; KI, 0.15; $\mathrm{Na}_{2} \mathrm{Se}_{2} \mathrm{O}_{3}, 0.01 ; \mathrm{MnSO}_{4} \_\mathrm{H}_{2} \mathrm{O}$ 2.0; $\mathrm{CoCl}_{2} \_6 \mathrm{H}_{2} \mathrm{O}, 1.0$. Concentrate feed was provided by the NongHyup Company. ${ }^{c}$ Vitamin premix contained the following ingredients (Power Vitamine, Genobio, Republic of Korea): Vitamin A, 6,000,000 IU; Vitamin D3, 1,200,000 IU; Vitamin E, 1000 mg; Vitamin B1, 500 mg; Vitamin B2, 500 mg; Vitamin B6, 500 mg; Vitamin B12, 10 mg; Protected Vitamin C, 5000 mg; Pantothenic acid, 1000 mg; Niacin, 1000 mg; Biotin, 30 mg; Folic acid, $600 \mathrm{mg} ; \mathrm{Mn}, 100 \mathrm{mg}$.

\subsection{Investigation of Fatty Acid}

Lipids were extracted with chloroform/methanol and then evaporated using a solvent evaporator (PT-MR3100 Kinematica, Luzern, Switzerland). In a dry bath (Type 16500, ThermoFisher Scientific, Waltham, MA, USA), chloroform was dried using nitrogen gas 
at $50{ }^{\circ} \mathrm{C}$. Lipid methylation was performed before the sample was injected into a gas chromatograph (HP 5890 II fixed with a G1513A auto-sampler; Hewlett Packard Co., Alto Palo, CA, USA). FA level was calculated with ultra-pure helium as a carrier gas (flux rate $=1.0 \mathrm{~mL} / \mathrm{min})$ using a silica capillary column $(100 \mathrm{~m} 0.25 \mathrm{~mm}$, i.e., $0.20-\mathrm{m}$ thickness, Supelco SP, Sigma-Aldrich, St. Louis, MO, USA). Injector and detector temperatures were kept at $250{ }^{\circ} \mathrm{C}$. The original oven temperature was set at $140{ }^{\circ} \mathrm{C}(30 \mathrm{~min})$. It was then increased to $220^{\circ} \mathrm{C}$ at $15^{\circ} \mathrm{C} / \mathrm{min}(40 \mathrm{~min})$ [22]. The free fatty acids in the samples were identified by comparing their retention times (RT) with standard RT of fatty acids (Sigma Aldrich, \# 47015U)

\subsection{Statistical Analysis}

Significant differences between control and experimental samples were analyzed with linear model procedures of SAS (SAS version 9.4, SAS Institute, Cary, NC, USA). Samples were analyzed in triplicate. Data are presented as mean \pm standard error of the means. Mean differences between two different feeding trials were analyzed using Duncan's multiple range tests. A statistically significant difference was considered at $p<0.05$.

\section{Results and Discussion}

\subsection{Nutrient Compositions}

We prepared Italian ryegrass and whole crop corn silages and fermented feed using lactic acid bacteria (LAB) as a biological additive in the current study. We then determined its nutrient profiles, such as Dry matter content $(\mathrm{DM})$, crude protein $(\mathrm{CP})$, Acid detergent fiber (ADF), Neutral detergent fiber (NDF), and Total digestible nutrient (TDN) in silages and fermented feed. The impact of silages and fermented feed on growth performance, carcass characteristics, and meat quality investigations during fattening periods in Korean cattle Hanwoo steers was studied and compared to commercial concentrate. Nutrient profiles, such as $\mathrm{CP}$ content $(8.40 \pm 0.13 ; 8.69 \pm 0.50)$ and TDN $(57.77 \pm 0.34 ; 68.06 \pm 0.97)$, slightly varied between Italian ryegrass (IRG) silage and whole crop corn (WCC) silage. However, rice straw had a very low $\mathrm{CP}$ content $(\mathrm{C} 4.40 \pm 0.05)$ and a moderate level of TDN $(55.65 \pm 0.15)$ compared to the silages. Dry matter content (DM) $(65.04 \pm 0.84 ; 68.04 \pm 0.34)$, $\operatorname{ADF}(39.41 \pm 0.43 ; 31.20 \pm 2.29)$, and NDF level of $(66.85 \pm 0.43 ; 46.82 \pm 2.12)$ of IRG and corn silage were lower compared to rice straw (DM: $88.50 \pm 0.40$; ADF: $42.10 \pm 0.19$; NDF: $69.09 \pm 0.12$ ) (Table 1). The nutrient profiles of IRG silage in this study were close to that of corn silage reported previously [28,29]. LABs are considered essential biological additives for silage production by rapid induction of fermentation process at ensiled condition. They can produce various organic acids, particularly lactic acid concentrations, which increase the acidification of silages. Rapid acidification prevented the yeast and mold growth in silages and preserved with high nutrients. Therefore, we used microbiological additives for animal feed production. It is a cost-effective strategy with high/similar effects compared to commercial feed. Heterofermentative lactic acid bacteria can promote acetic acid biosynthesis, thus improving the aeration of silage and its quality. On the other hand, water-soluble carbohydrates are fermented by homofermentative bacterial inoculants into organic acids, especially lactic acid, which can quickly acidify silage and inhibit the growth of undesirable bacteria. To regulate the growth of yeast, homolactic inoculants, such as lactobacilli, known to produce acids, such as acetic and propionic acids, that inhibit the growth of microorganisms that trigger spoilage [30] were added. Inoculants include one or two groups of acidophilic bacteria. During co-fermentation, the synthesis of acetic acid, 1,2-propanediol, and propionic acid was stimulated by bacterial strains of these species. They make sustainable feed silage more aerobically stable. The findings of the study could be used to establish bacterial preparations that can facilitate the ensilage of renewable raw materials. 


\subsection{Growth Performance}

Next, we investigated the impact of our formulated feed (Silage and fermented feed) on growth performance of Hanwoo steers. A significant amount of dietary roughage is essential in TMR for healthy rumination [31]. Dietary intake is essential to meet maintenance and production requirements. It has been reported that the nature of feed and environmental conditions also plays a key role in the feed intake of animals. This study replaced the concentrate and rice straw with formulated feed and fed it to animals for 13 months. Animals fed with formulated feed showed higher feed intake during early fattening $(16.29 \pm 0.73)$ as well as late fattening $(17.79 \pm 0.54)$ periods than the animals fed with control feed $(11.50 \pm 0.73$ vs. $14.36 \pm 0.54$ (Table 3$)$. These data suggest that the animals had more interested in eating formulated feed than the control feed. It might be due to microbially fermented silages. It contains various organic acids, which make good smells and taste. A similar experiment with other silages was conducted in Hanwoo steers; this study's author reported that the total feed intake was higher in animals fed with mixed silage and concentrate than the concentrate with rice straw [32]. Our previous experimental data also showed Hanwoo steers fed with IRG silage had a higher feed intake average compared to concentrate with rice straw [28]. However, Teixeira Junior reported that animals fed silage have lower feed consumption than control diet [33] which is different from our findings. The increase in nutrient intake by the treatment group might have resulted in an enhanced metabolic balance by gain or changes in fermentation expansion. The initial body weight average of Hanwoo steers was $376.4 \mathrm{~kg}$ for the control group and $415.0 \mathrm{~kg}$ for the treatment group during the early fattening period. In the late fattening period, the average body weight for the control group was $575.8 \mathrm{~kg}$, and for the treatment group was $624.4 \mathrm{~kg}$. The final body weight average of formulated fed Hanwoo steers was $595.0 \mathrm{~kg}$ during the early fattening period and $751.6 \mathrm{~kg}$ during the late fattening period. As shown in Table 3, the average daily gain of Hanwoo steers fed with formulated feed was significantly higher than that of Hanwoo steers fed with control feed during both the early and late fattening periods (both $p<0.05$ ). These results showed that the average daily gain during the early fattening period was higher than that during the late fattening period. It indicates that the animals treated with our formulated feed increased daily feed intake compared to the control fed animals; it might influence the increase in average daily gain during the experimental period. These data confirmed that the replacement of concentrate with fermented silages and feed had a significant impact on animal performance. These data are consistent with Lin et al. [34], who also found that fermented feed supplementation could improve feed intake, average daily gain, and feed conservation ratio of Hanwoo steers. Cho et al. [35] and Kim et al. [21] also reported an increase in total feed intake and a decrease in the intake of concentrate for cattle fed with fermented silage compared to those fed with a roughage feeding system. In fact, a lower nutritional value of the feed could not help but decrease nutrient concentration and rumen wealth. Our research found that formulated feed could alter moisture content and nutrition consumption that potentially enhance body weight gain. The feed conversion ratio was significant in Hanwoo steers fed with formulated feed compared to control in the early fattening period than that of the late fattening period $(p<0.05)$. It demonstrated that feeds containing a large portion of grass silage can sustain growth rates, leading to a greater fat deposit. Overall study reports confirmed that the replacement of silages and fermented feed significantly improve the animal's performances than the concentrated and rice straw fed animals. 
Table 3. Effects of formulated feed on growth performance and feed intake of Hanwoo steers during early and late feeding periods.

\begin{tabular}{|c|c|c|c|c|c|c|c|c|c|c|c|c|}
\hline \multirow{2}{*}{ Items } & \multicolumn{4}{|c|}{ Early Fattening Period } & \multicolumn{4}{|c|}{ Late Fattening Period } & \multicolumn{4}{|c|}{ Total Period } \\
\hline & $\mathrm{CON}^{1}$ & $T^{2}$ & SEM $^{3}$ & $p$-Value & $\mathrm{CON}$ & $\mathrm{T}$ & SEM & $p$-Value & $\mathrm{CON}$ & $\mathbf{T}$ & SEM $^{3}$ & $p$-Value \\
\hline IBW $(\mathrm{kg})$ & 376.4 & 415.0 & 11.50 & 0.26 & 575.8 & 624.4 & 1.47 & 0.03 & 376.4 & 415.0 & 11.5 & 0.26 \\
\hline FBW (kg) & 538.8 & 595.1 & 14.80 & 0.04 & 696.0 & 751.6 & 17.4 & 0.03 & 696.0 & 751.6 & 17.40 & 0.03 \\
\hline ADG $(\mathrm{kg})$ & 0.83 & 0.93 & 0.04 & 0.05 & 0.76 & 0.83 & 0.05 & 0.20 & 0.79 & 0.88 & 0.02 & 0.22 \\
\hline Feed intake (kg) & 11.50 & 16.29 & 0.73 & - & 14.36 & 17.79 & 0.54 & - & 12.93 & 17.04 & 0.49 & - \\
\hline Concentrate (kg) & 8 & - & - & - & 12.57 & 6.43 & - & - & 10.29 & 3.21 & - & - \\
\hline Rice straw (kg) & 3.5 & - & - & - & 1.79 & 0.79 & - & - & 2.64 & 0.39 & - & - \\
\hline IRG silage (kg) & - & 3 & - & - & - & 1.29 & - & - & - & 2.14 & - & - \\
\hline WCC silage (kg) & - & 5.86 & - & - & - & 0.43 & - & - & - & 3.14 & - & - \\
\hline Fermented feed $(\mathrm{kg})$ & - & 7.43 & - & - & - & 8.86 & - & - & - & 8.14 & - & - \\
\hline FCR & 15.83 & 18.55 & 0.79 & 0.82 & 23.27 & 24.18 & 1.61 & 0.56 & 20.51 & 19.18 & 0.64 & 0.59 \\
\hline
\end{tabular}

${ }^{1}$ Control group: Hanwoo steers fed rice straw + concentrate; ${ }^{2}$ Treatment group: Hanwoo steers fed IRG silage + WCC silage + fermented feed; IBW: Initial body weight; FBW: Final body weight; ADG: Average daily gain; IRG: Italian ryegrass; WCC: whole crop corn; FCR: Feed conversion ratio; ${ }^{3}$ Standard error of the mean ( $p$-value).

\subsection{Carcass and Meat Quality Characteristics}

Our formulated feed shows significant positive impacts on body weight and feed intakes. Then we analyzed the effects of formulated feed supplementation on carcass yield and quality characteristics of Hanwoo steers during early and late fattening periods. Results are shown in Table 4 . Carcass weight (control $401.8 \mathrm{~kg}$ vs. treatment $444 \mathrm{~kg}$ ) and ribeye area (control $87.6 \mathrm{~cm}^{2}$ vs. treatment $91 \mathrm{~cm}^{2}$ ) of formulated fed Hanwoo steers were substantially increased compared to those of control feed fed Hanwoo steers (both $p<0.05$ ). However, backfat thickness (control $10 \mathrm{~mm}$ vs. treatment $13.20 \mathrm{~mm}$ ), dressing percent, and quantity characteristics, such as marbling score, meat color, fat color, texture, and quality grade, were similar between treatment and control group of Hanwoo steers throughout the experimental period. The findings of the present study were consistent with those of Kim et al. [28]. They reported that carcass weight and ribeye area of Hanwoo steers were enhanced by feeding IRG silage. Kim et al. [21] also reported similar results, showing that the carcass weight of steers was significantly decreased when concentrate supplementation was provided, consistent with our data. Table 5 summarizes chemical compositions (percentage of moisture, crude fat, crude protein, and ash) and meat quality (such as cooking loss, shear force, water holding capacity, surface color, and sensory evaluation) of treatment/control group animals Hanwoo steers. A slight increase in moisture percentage was noted in animals fed with formulated feed compared to animals fed with concentrate. Crude fat and protein level remained unchanged between control and treatment group animals. For the meat qualities study, less cooking loss was noted for animals treated with formulated feed than the control animals $(p<0.05)$. Shear force, water holding capacity, and $\mathrm{pH}$ were not changed significantly between control and treated group animals. In addition, surface color and sensory evaluation were similar in control and treatment group animals. Overall acceptability is slightly higher for animals treated with formulated feed than control animals fed with concentrate and rice straw. Duckett et al. [36] also reported that intramuscular fat content and palatability can be improved by moving from a forage feed to a high concentrated feed at 40 days prior to slaughter. Kerth et al. [37] indicated that cattle finished on forage have subcutaneous fat that is more yellow in color compared to grain-finished cattle, which might be a drawback for the customer to consider forage-finished beef. Scheffler and Gerrard [38] suggested that postmortem glycogen is converted to lactate and $\mathrm{H}^{+}$, resulting in a decrease in the $\mathrm{pH}$ of meat and that the amount of glycogen at slaughter is inversely linked to the ultimate pH. Wicks et al. [39] proposed that a high energy feed could increase postmortem glycolysis ability, leading to an extended $\mathrm{pH}$ decline and a lower final $\mathrm{pH}$. Overall data confirmed that the low-cost silage and fermented feed could improve the animal performance and meat quality by either increasing/similar to high-cost concentrate fed animals. 
Table 4. Carcass characteristics and quality traits of Hanwoo steers fed control or formulated feed.

\begin{tabular}{|c|c|c|c|c|}
\hline Items & $\mathrm{CON}^{1}$ & $\mathrm{~T}^{2}$ & SEM $^{3}$ & ${ }^{4} p$-Value \\
\hline \multicolumn{5}{|l|}{ Carcass characteristics } \\
\hline Carcass weight (kg) & 401.80 & 444.00 & 12.9 & 0.02 \\
\hline Backfat thickness (mm) & 10.00 & 13.20 & 0.9 & 0.18 \\
\hline Ribeye area $\left(\mathrm{cm}^{2}\right)$ & 87.60 & 91.00 & 2.1 & 0.05 \\
\hline Dressing percent $(\%)$ & 59.80 & 61.80 & 0.8 & 0.24 \\
\hline Quantity grade 5 & 67.00 & 64.60 & 0.8 & 0.2 \\
\hline \multicolumn{5}{|l|}{ Quality traits } \\
\hline Marbling score 6 & 4.60 & 5.00 & 0.7 & 0.52 \\
\hline Lean color ${ }^{7}$ & 5.00 & 4.80 & 0.1 & 0.51 \\
\hline Fat color 8 & 3.00 & 2.80 & 0.1 & 0.51 \\
\hline Texture $^{9}$ & 1.40 & 1.20 & 0.2 & 0.13 \\
\hline Mature 10 & 2.00 & 2.40 & 0.1 & 0.4 \\
\hline Quality grade ${ }^{11}$ & 4.00 & 4.40 & 0.3 & 0.57 \\
\hline Total price (KRW / steer) & $8,863,074$ & $8,459,352$ & 31,782 & 0.05 \\
\hline
\end{tabular}

${ }^{1}$ Control: Rice straw + concentrate; ${ }^{2}$ Treatment: IRG silage + WCC silage + fermented feed; ${ }^{3}$ Standard error of the mean; ${ }^{4}$ Significance levels; ${ }^{5}$ grade A (5 point) grade D $(2$ point $) ;{ }^{6}$ low fat $(1$ point $) \sim$ high fat $(5$ point $)$ ${ }^{7}$ very light cherry red (1 point) very dark red $(7$ point $) ;{ }^{8}$ white $(1$ point $) \sim$ yellow $(7$ point $) ;{ }^{9}$ very fine $(1$ point $)$ $\sim$ very coarse ( 3 point); ${ }^{10}$ below 15 -month-old (1 point) from 15 to 26 months old ( 2 point); ${ }^{11}$ grade $1+(7$ point) $\sim$ grade 3 (1point). IRG: Italian ryegrass; WCC: whole crop corn.

Table 5. Chemical compositions and meat quality characteristics of control or treatment animals.

\begin{tabular}{|c|c|c|c|c|}
\hline Items & $\mathrm{CON}^{1}$ & $\mathrm{~T}^{2}$ & SEM $^{3}$ & ${ }^{4} p$-Value \\
\hline \multicolumn{5}{|l|}{ Chemical compositions } \\
\hline Moisture $(\%)$ & 62.23 & 64.00 & 0.89 & 0.30 \\
\hline Crude fat $(\%)$ & 14.38 & 14.34 & 1.18 & 0.47 \\
\hline Crude protein $(\%)$ & 20.81 & 20.98 & 0.39 & 0.80 \\
\hline Ash $(\%)$ & 0.85 & 0.85 & 0.02 & 0.32 \\
\hline \multicolumn{5}{|l|}{ Meat qualities } \\
\hline Cooking loss (\%) & 19.89 & 19.63 & 0.67 & 0.50 \\
\hline Shear force $(\mathrm{kg})$ & 4.43 & 3.12 & 0.43 & 0.59 \\
\hline Water holding capacity (\%) & 56.80 & 57.17 & 0.52 & 0.39 \\
\hline $\mathrm{pH}$ & 5.51 & 5.51 & 0.03 & 0.19 \\
\hline \multicolumn{5}{|l|}{ Surface color } \\
\hline CIE L * & 39.07 & 38.49 & 0.65 & 0.99 \\
\hline$a^{*}$ & 24.08 & 21.94 & 0.72 & 0.67 \\
\hline$b^{*}$ & 11.50 & 9.83 & 0.52 & 0.66 \\
\hline Hunter L * & 32.71 & 32.21 & 0.57 & 0.99 \\
\hline$a^{*}$ & 19.24 & 17.35 & 0.68 & 0.76 \\
\hline$b^{*}$ & 7.40 & 6.36 & 0.35 & 0.72 \\
\hline \multicolumn{5}{|l|}{ Sensory evaluation } \\
\hline Color & 3.33 & 3.81 & 0.10 & 0.05 \\
\hline Aroma & 3.38 & 3.16 & 0.13 & 0.41 \\
\hline Juiciness & 3.56 & 3.80 & 0.11 & 0.26 \\
\hline Texture & 3.48 & 3.88 & 0.10 & 0.06 \\
\hline Overall acceptability & 3.47 & 3.81 & 0.10 & 0.09 \\
\hline
\end{tabular}

${ }^{1}$ control: Rice straw + concentrate; ${ }^{2}$ Treatment: IRG silage + WCC silage + fermented feed; ${ }^{3}$ Standard error of the mean; ${ }^{4}$ Significance levels; ${ }^{*}$ CIE: International Commission on Illumination. IRG: Italian ryegrass; WCC: whole crop corn. L-lightness; a-redness; $b$-yellowness.

\subsection{Fatty Acid Analysis}

Many reports claim that forage feeding system as opposed to concentrate feeding resulted in beneficial changes in the fatty acids of meat, particularly a shift in n- 6 to n-3 PUFA ratio and elevated levels of CLA (conjugated linoleic acid) [40,41]. Lee et al. reported that red clover silage-fed animals had higher proportions of C18: 3-n, total n-3 fatty acids, and PUFA compared to animals fed with grass silage [42]. Ye et al. [43] reported that 
silage-based beef had higher polyunsaturated fatty acids (n3) than concentrate-based beef. In the current study, C14:0, C16:0, C16:1-n-7, C18:0, C18:1n-9, C18:3n-6, C18:2-n-6, C18:3n-3, $\mathrm{C} 20: 1 \mathrm{n}-9$, and C20:4n-6, were analyzed in the meat of animal fed concentrated and animal fed formulated feed. These fatty acids profiles were not altered significantly between control and treatment group animals. However, we noted slight changes in C14:0 (myristic acid), C16:1n-7 (palmitic acid), and C20:1n-9 (eicosanoic acid) between experimental groups. The calculated saturated, unsaturated, monounsaturated, and polyunsaturated fatty acid profiles remained unchanged in control and treatment animals. At the same time, a slight increase in unsaturated fatty acid was noted in the animals fed formulated feed compared to concentrate fed animals. The $\omega 6 / \omega 3$ ratio was lower for animals fed formulated feed than the control group (Table 6). Overall data suggested that the formulated feed supplementation did not alter fatty acid profiles in the meat compared to concentrate-fed animals. Our study was slightly inconsistent with previous studies, which may be due to differences in the animal breed, plant-based silages, and production.

Table 6. Fatty acid compositions in Hanwoo steers fed with control or formulated feed.

\begin{tabular}{ccccc}
\hline Items & CON $^{\mathbf{1}}$ & $\mathbf{T}^{\mathbf{2}}$ & SEM $^{\mathbf{3}}$ & ${ }^{4} p$-Value \\
\hline C14:0 (myristic) & 3.12 & 2.8 & 0.12 & 0.87 \\
C16:0 (palmitic) & 28.02 & 28.29 & 0.43 & 0.42 \\
C16:1n-7 (palmitoleic) & 4.91 & 4.31 & 0.18 & 0.31 \\
C18:0 (stearic) & 11.91 & 11.79 & 0.42 & 0.98 \\
C18:1n-9 (oleic) & 49.19 & 49.92 & 0.57 & 0.39 \\
C18:3n-6 ( $\gamma$-linolenic) & 0.11 & 0.13 & 0.01 & 0.08 \\
C18:2n-6 (linoleic) & 2.04 & 1.98 & 0.11 & 0.51 \\
C18:3n-3 ( $\alpha$-linolenic) & 0.04 & 0.04 & 0.00 & 0.98 \\
C20:1n-9 (eicosanoic) & 0.51 & 0.60 & 0.04 & 0.76 \\
C20:4n-6 (arachidonic) & 0.15 & 0.15 & 0.02 & 0.97 \\
Saturated fatty acid (SFA) & 43.05 & 42.88 & 0.49 & 0.55 \\
Unsaturated fatty acid (UFA) & 56.95 & 59.12 & 0.49 & 0.55 \\
Monounsaturated fatty acid (MUFA) & 54.61 & 54.83 & 0.55 & 0.48 \\
Polyunsaturated fatty acid (PUFA) & 2.34 & 2.30 & 0.14 & 0.63 \\
$\omega 3$ & 0.11 & 0.13 & 0.01 & 0.08 \\
$\omega 6$ & 2.23 & 2.17 & 0.13 & 0.65 \\
$\omega 6 / \omega 3$ & 20.92 & 16.69 & 0.98 & 0.46 \\
\hline
\end{tabular}

${ }^{1}$ control: Rice straw + concentrate; ${ }^{2}$ Treatment: IRG silage + WCC silage + fermented feed; ${ }^{3}$ Standard error of the mean; ${ }^{4}$ Significance level. IRG: Italian ryegrass; WCC: whole crop corn.

There were few limitations to the present study, (I) sample size was relatively small; (II) blood parameters are essential to confirm the new feed impact on the clinical markers, particularly cytokines, but we did not analyze the clinical parameters change in the control and treatment animals; (III) gut microbiota plays a significant role in animal growth performances, so microbiome study is essential to confirm the microbial changes in the experimental animals. Advantages of the current study: we replaced commercial concentrate with fermented feed; it was prepared from grass, legume, and other natural substrates by microbial fermentation. Our formulated feed showed significant positive impacts on the animal's growth performance and meat quality. It is a very cost-effective strategy that reduces the economic burden for livestock cultivars. Future aspect study: in-depth study is required to determine the changes in mRNA expressions in response to formulated feed supplementation, intramuscular fat deposition status, cytokines, adipokines and myokines changes, and associated microbiome mechanisms.

\section{Conclusions}

The feed cost indicates the most extensive single variable in beef production. Therefore, in the current study, we partially replaced concentrate feed with naturally fermented IRG, corn, and feed for animal performances in Hanwoo steers. The data suggest that fermented feed-fed animals had significant daily body weight gain, carcass weight, and ribeye area 
than the control animals. In addition, carcass characteristics, meat quality, and fatty acid profiles remained unchanged in control and formulated fed animals. It confirmed that replacement of concentrate with low-cost fermented feed has a significant impact on the animal performance higher/similar to control diet. It suggested that our formulated feed usage could be considered a cost-effective strategy to improve animal performance. Further, in-depth study in formulated feed and its impact on animal performance will be required in the future.

Author Contributions: Conceptualization, K.-C.C. and J.-S.J.; methodology and validation, K.-C.C., and D.K.; formal analysis, D.K. and J.-S.J.; writing-original draft preparation, D.K. and J.-S.J.; supervision and funding acquisition, K.-C.C. All authors have read and agreed to the published version of the manuscript.

Funding: This research was funded by a Cooperative Research Program for Agriculture Science \& Technology Development Project (Project No. PJ0149822021 entitled Development of fundamental technology for public ranch management of growing Hanwoo steers using public hilly pasture.

Institutional Review Board Statement: The study was designed and conducted according to animal care and standard guidelines of the National Institute of Animal Science, South Korea (Approval Number NIAS-2020-443, Approval date: 17 February 2020).

Informed Consent Statement: Not applicable.

Data Availability Statement: The data presented in this study are available on request from the corresponding author.

Conflicts of Interest: The authors have no potential conflict of interest relevant to this study to disclose.

\section{References}

1. Jeong, C.-D.; Mamuad, L.L.; Ko, J.Y.; Sung, H.G.; Park, K.K.; Lee, Y.K.; Lee, S.-S. Rumen fermentation and performance of Hanwoo steers fed total mixed ration with Korean rice wine residue. J. Anim. Sci. Technol. 2016, 58, 4. [CrossRef] [PubMed]

2. Chung, K.Y.; Lee, S.H.; Cho, S.H.; Kwon, E.G.; Lee, J.H. Current situation and future prospects for beef production in South Korea-A review. Asian-Australas. J. Anim. Sci. 2018, 31, 951-960. [CrossRef] [PubMed]

3. Lee, S.H.; Park, E.W.; Cho, Y.M.; Kim, S.K.; Lee, J.H.; Jeon, J.T.; Lee, C.S.; Im, S.K.; Oh, S.J.; Thompson, J.M.; et al. Identification of differentially expressed genes related to intramuscular fat development in the early and late fattening stages of hanwoo steers. J. Biochem. Mol. Biol. 2007, 40, 757-764. [CrossRef] [PubMed]

4. Lee, D.H. Methods for genetic parameter estimations of carcass weight, longissimus muscle area and marbling score in korean cattle. J. Anim. Sci. Technol. 2004, 46, 509-516.

5. Lee, S.M.; Kim, J.Y.; Kim, E.J. Effects of stocking density or group size on intake, growth, and meat quality of hanwoo steers (Bos taurus coreanae). Asian-Australas. J. Anim. Sci. 2012, 25, 1553-1558. [CrossRef] [PubMed]

6. Neubauer, V.; Petri, R.M.; Humer, E.; Kröger, I.; Reisinger, N.; Baumgartner, W.; Wagner, M.; Zebeli, Q. Starch-rich diet induced rumen acidosis and hindgut dysbiosis in dairy cows of different lactations. Animals 2020, 10, 1727. [CrossRef] [PubMed]

7. Ogata, T.; Makino, H.; Ishizuka, N.; Iwamoto, E.; Masaki, T.; Ikuta, K.; Kim, Y.-H.; Sato, S. Long-term high-grain diet altered the ruminal $\mathrm{pH}$, fermentation, and composition and functions of the rumen bacterial community, leading to enhanced lactic acid production in Japanese Black beef cattle during fattening. PLoS ONE 2019, 14, e0225448. [CrossRef] [PubMed]

8. Huang, H.; von Lampe, M.; van Tongeren, F. Climate change and trade in agriculture. Food Policy 2011, 36, S9-S13. [CrossRef]

9. Al-Thuwaini, T.; Al-Shuhaib, M.B. The effects of grass-based versus grain-based feeding of ruminants on the human hygienic status, a Review. World Vet. J. 2019, 9, 174-180. [CrossRef]

10. Daley, C.A.; Abbott, A.; Doyle, P.S.; Nader, G.A.; Larson, S. A review of fatty acid profiles and antioxidant content in grass-fed and grain-fed beef. Nutr. J. 2010, 9, 10. [CrossRef] [PubMed]

11. Niderkorn, V.; Baumont, R. Associative effects between forages on feed intake and digestion in ruminants. Anim. Int. J. Anim. Biosci. 2009, 3, 951-960. [CrossRef] [PubMed]

12. Uzun, P.; Masucci, F.; Serrapica, F.; Napolitano, F.; Braghieri, A.; Romano, R.; Manzo, N.; Esposito, G.; Di Francia, A. The inclusion of fresh forage in the lactating buffalo diet affects fatty acid and sensory profile of mozzarella cheese. J. Dairy Sci. 2018, 101, 6752-6761. [CrossRef] [PubMed]

13. Weiss, C.P.; Gentry, W.W.; Meredith, C.M.; Meyer, B.E.; Cole, N.A.; Tedeschi, L.O.; McCollum, F.T.; Jennings, J.S. Effects of roughage inclusion and particle size on digestion and ruminal fermentation characteristics of beef steers. J. Anim. Sci. 2017, 95, 1707-1714. [CrossRef] [PubMed]

14. Bueno, A.V.; Lazzari, G.; Jobim, C.C.; Daniel, J.L. Ensiling total mixed ration for ruminants: A review. Agronomy $2020,10,879$. [CrossRef] 
15. Kim, S.H.; Alam, M.J.; Gu, M.J.; Park, K.W.; Jeon, C.O.; Ha, J.K.; Cho, K.K.; Lee, S.S. Effect of total mixed ration with fermented feed on ruminal in vitro fermentation, growth performance and blood characteristics of hanwoo steers. Asian-Australas. J. Anim. Sci. 2012, 25, 213-223. [CrossRef]

16. McGrath, J.; Duval, S.M.; Tamassia, L.F.M.; Kindermann, M.; Stemmler, R.T.; de Gouvea, V.N.; Acedo, T.S.; Immig, I.; Williams, S.N.; Celi, P. Nutritional strategies in ruminants: A lifetime approach. Res. Vet. Sci. 2018, 116, 28-39. [CrossRef]

17. Xie, Y.; Xu, S.; Li, W.; Wang, M.; Wu, Z.; Bao, J.; Jia, T.; Yu, Z. Effects of the application of lactobacillus plantarum inoculant and potassium sorbate on the fermentation quality, In Vitro digestibility and aerobic stability of total mixed ration silage based on alfalfa silage. Animals 2020, 10, 2229. [CrossRef]

18. Agarussi, M.C.N.; Pereira, O.G.; de Paula, R.A.; da Silva, V.P.; Roseira, J.P.S.; e Silva, F.F. Novel lactic acid bacteria strains as inoculants on alfalfa silage fermentation. Sci. Rep. 2019, 9, 8007. [CrossRef] [PubMed]

19. Soundharrajan, I.; Kuppusamy, P.; Park, H.; Kim, J.; Kim, W.; Jung, J.; Choi, K. Lactic acid bacteria mixture as inoculants on low moisture italian ryegrass silage fermentation. J. Korean Soc. Grassl. Forage Sci. 2019, 39, 127-131. [CrossRef]

20. Kim, D.H.; Amanullah, S.M.; Lee, H.J.; Joo, Y.H.; Kim, S.C. Effect of Microbial and Chemical Combo Additives on Nutritive Value and Fermentation Characteristic of Whole Crop Barley Silage. Asian-Australas. J. Anim. Sci. 2015, 28, 1274-1280. [CrossRef]

21. Kim, T.I.; Mayakrishnan, V.; Lim, D.H.; Yeon, J.H.; Baek, K.S. Effect of fermented total mixed rations on the growth performance, carcass and meat quality characteristics of Hanwoo steers. Anim. Sci. J. 2018, 89, 606-615. [CrossRef]

22. Arasu, M.V.; Jung, M.-W.; Kim, D.H.; Ilavenil, S.; Jane, M.; Park, H.S.; Al-Dhabi, N.A.; Jeon, B.T.; Choi, K.C. Enhancing nutritional quality of silage by fermentation with lactobacillus plantarum. Indian J. Microbiol. 2014, 54, 396-402. [CrossRef] [PubMed]

23. Official Methods of Analysis of AOAC International, 16th ed.; AOAC International: Washington, DC, USA, $1995 ;$ Volume 1.

24. Serrapica, F.; Masucci, F.; Raffrenato, E.; Sannino, M.; Vastolo, A.; Barone, C.M.A.; Di Francia, A. High fiber cakes from mediterranean multipurpose oilseeds as protein sources for ruminants. Animals 2019, 9, 918. [CrossRef] [PubMed]

25. Al-Mentafji, H.N. AOAC, Official Methods of Analysis, 18th ed; AOAC International: Rockville, MD, USA, 2005.

26. Chang, C.W. Nutrient requirement for maintenance and nutritional changes of the Hanwoo steers in early-fattening stage under heat stress. Korean J. Agric. Sci. 2018, 45, 74-83.

27. Kang, S.N.; Song, Y.-M.; Kim, C.-W.; Kim, T.-W.; Chu, G.-M.; Yang, B.-S.; Jin, S.-K.; Kim, I.-S. Effect of feeding high carbohydratelow fat fermented feed on the meat quality characteristics in finishing pigs. Korean J. Food Sci. Anim. Resour. 2010, 30, 826-832. [CrossRef]

28. Kim, W.H.; Kang, S.-N.; Arasu, M.V.; Chu, G.-M.; Kim, D.H.; Park, J.-H.; Oh, Y.K.; Choi, K.C. Profile of hanwoo steer carcass characteristics, meat quality and fatty acid composition after feeding italian ryegrass silage. Korean J. Food Sci. Anim. Resour. 2015, 35, 299-306. [CrossRef] [PubMed]

29. Kim, W.; Seo, S.; Yoon, S.H.; Kim, K.Y.; Cho, Y.M.; Park, T.I.; Koh, J.M.; Park, G.J. Selection of promising barley cultivar for silage 2. Nutrient value and total digestible nutrient yield. J. Korean Soc. Grassl. Forage Sci. 2003, 23, 283-288. [CrossRef]

30. Selwet, M. Influence of inoculation with lactobacillus on fermentation, production of 1,2-propanediol and 1-propanol as well as Maize silage aerobic stability. Open Life Sci. 2020, 15, 373-378. [CrossRef] [PubMed]

31. Jiang, F.G.; Lin, X.Y.; Yan, Z.G.; Hu, Z.Y.; Liu, G.M.; Sun, Y.D.; Liu, X.W.; Wang, Z.H. Effect of dietary roughage level on chewing activity, ruminal $\mathrm{pH}$, and saliva secretion in lactating Holstein cows. J. Dairy Sci. 2017, 100, 2660-2671. [CrossRef]

32. Lee, S.-M.; Kim, Y.-I.; Kwak, W.S. Effect of by-product mixing silage feeding on the eating and ruminating behavior of hanwoo steer. J. Korean Soc. Grassl. Forage Sci. 2010, 30, 159-168. [CrossRef]

33. Junior, D.T.; Missio, R.L.; Sforcini, M.P.R.; de Oliveira, M.D.S.; Ferrari, V.B.; Santos, R.F. Productive performance of dairy cows fed with hydrolyzed sugarcane. Ciência Rural. 2015, 45, 1848-1853. [CrossRef]

34. Lin, H.; Decuypere, E.; Buyse, J. Oxidative stress induced by corticosterone administration in broiler chickens (Gallus gallus domesticus) 2. Short-term effect. Comparative biochemistry and physiology. Part. B Biochem. Mol. Biol. 2004, 139, 745-751. [CrossRef] [PubMed]

35. Cho, W.-M.; Chang, S.-S.; Cho, Y.; Kim, H.-C.; Kwon, E.-G.; Yang, S.-H.; Paek, B.-H. Effects of forage source and shipping time on growth performance and carcass characteristics of hanwoo steers. J. Korean Soc. Grassl. Forage Sci. 2009, $29,375-382$.

36. Duckett, S.; Neel, J.; Lewis, R.; Fontenot, J.; Clapham, W. Effects of forage species or concentrate finishing on animal performance, carcass and meat quality. J. Anim. Sci. 2013, 91, 1454-1467. [CrossRef] [PubMed]

37. Kerth, C.; Braden, K.; Cox, R.; Kerth, L.K.; Rankins, D.L. Carcass, sensory, fat color, and consumer acceptance characteristics of Angus-cross steers finished on ryegrass (Lolium multiflorum) forage or a high-concentrate diet. Meat Sci. 2007, 75, 324-331. [CrossRef] [PubMed]

38. Scheffler, T.L.; Gerrard, D.E. Mechanisms controlling pork quality development: The biochemistry controlling postmortem energy metabolism. Meat Sci. 2007, 77, 7-16. [CrossRef]

39. Wicks, J.; Beline, M.; Gomez, J.F.; Luzardo, S.; Silva, S.L.; Gerrard, D. Muscle energy metabolism, growth, and meat quality in beef cattle. Agriculture 2019, 9, 195. [CrossRef]

40. Dannenberger, D.; Nuernberg, G.; Scollan, N.; Ender, K.; Nuernberg, K. Diet alters the fatty acid composition of individual phospholipid classes in beef muscle. J. Agric. Food Chem. 2007, 55, 452-460. [CrossRef]

41. Nuernberg, K.; Dannenberger, D.; Nuernberg, G.; Ender, K.; Voigt, J.; Scollan, N.D.; Wood, J.D.; Nute, G.R.; Richardson, R.I. Effect of a grass-based and a concentrate feeding system on meat quality characteristics and fatty acid composition of longissimus muscle in different cattle breeds. Livest. Prod. Sci. 2005, 94, 137-147. [CrossRef] 
42. Lee, M.R.F.; Evans, P.R.; Nute, G.R.; Richardson, R.I.; Scollan, N.D. A comparison between red clover silage and grass silage feeding on fatty acid composition, meat stability and sensory quality of the M. Longissimus muscle of dairy cull cows. Meat Sci. 2009, 81, 738-744. [CrossRef]

43. Ye, Y.; Eyres, G.T.; Reis, M.G.; Schreurs, N.M.; Silcock, P.; Agnew, M.P.; Johnson, P.L.; Maclean, P.; Realini, C.E. Fatty acid composition and volatile profile of $M$. longissimus thoracis from commercial lambs reared in different forage systems. Foods 2020, 9, 1885. [CrossRef] [PubMed] 